\title{
The Performance appraisal Research of Manufacturing Department Based on AHP
}

\author{
Di Liang ${ }^{1, a}$, Guizhi Sun ${ }^{1, b}$,Shuang $\mathrm{Wu}^{1, \mathrm{c}}$ \\ ${ }^{1}$ School of Mechanical Engineering, Shenyang University, Shenyang, Liaoning Province, China \\ asydxld@163.com, bsungz1992@163.com, '445391942@qq.com
}

Keywords: Manufacturing enterprises;Department performance appraisal;AHP;The fuzzy comprehensive evaluation method

\begin{abstract}
X company mainly produces electric locomotive and urban rail vehicles. This paper takes the locomotive department of X company as the research object. It builds a performance management system by using AHP and fuzzy evaluation method. It constructs the index system by using the idea of BSC, questionnaire survey and expert interviews method. It analyzes the correlation of index combined the MINITAB software. It set evaluation scales by using cluster analysis, then conducts fuzzy comprehensive evaluation. Building performance evaluation system of $\mathrm{X}$ company's manufacturing system can solve the problems of department performance evaluation effectively.
\end{abstract}

\section{Introduction}

Performance should be defined as the result of the work, because the results of the work and the organization's strategic objectives has the most closely related to customer satisfaction and investment [1].Performance as output is an important way to evaluating the effectiveness of behavior [2]. An enterprise wants to get advantage in the fierce market competition, it must improve its overall effectiveness and performance constantly [3].

Most of domestic researches also only stay in discussion on problems of performance appraisal tool $[4,5]$, the study of department performance evaluation is relatively less.This paper takes on the production system of $\mathrm{X}$ company as the research object. It creates a new performance management system model by using the basic theory of performance management and ideas, combining with the characteristics of enterprise manufacturing system and the understanding of the company strategic objectives. The index system is built by using the idea of the BSC, a questionnaire survey and expert interview method. AHP and Delphi method is used to determine index weight, and the fuzzy comprehensive method is used to evaluate.

\section{The Overall Building of X Company Production Performance Management System}

In this paper, the study of production system performance belong to the department performance. It includes the target system and management process.

Performance management includes four links: performance planning, performance implementation and management, performance evaluation and feedback. The performance management framework is shown in figure 1:

\section{The Analysis of Production System Performance Problem}

$\mathrm{X}$ company mainly produces electric locomotive and the urban rail vehicles. X company manufacturing systems include locomotive department, city rail group and bogie group. The three divisions are production entity departments, the nature of management is different from other departments. The performance evaluation method of department is not perfect,and it has many problems now: there is no complete performance management system; The performance evaluation become a mere formality. The performance appraisal process has less communication and lack of performance training. 


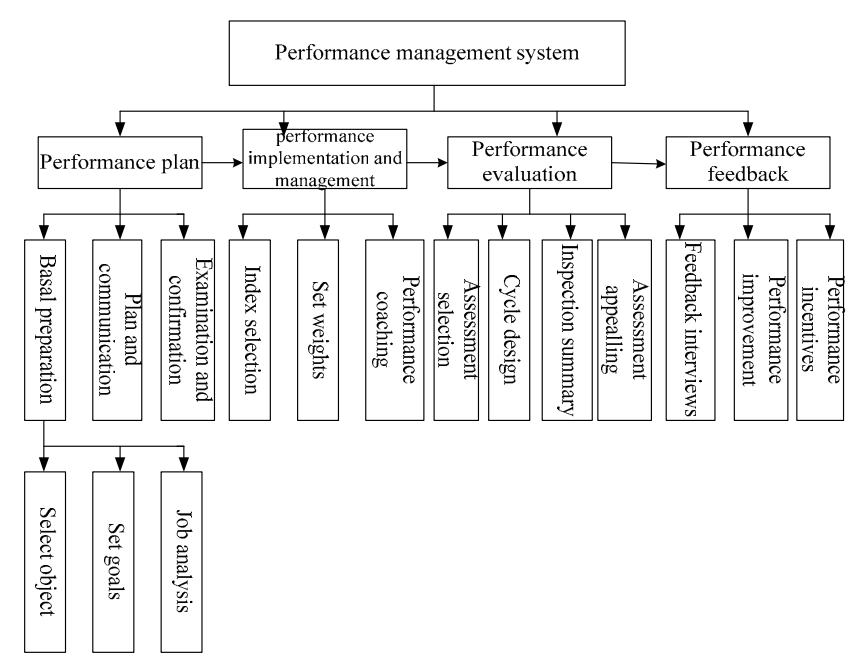

Fig. 1 Performance management framework chart

\section{The Implementation of X Company Production Performance Management System}

This paper takes the locomotive department as the research object. The locomotive department is examined. This paper focuses on locomotive department performance evaluation.

The Establishment of the Index System. According to the actual situation of enterprises and the research results previously, BSC and KPI to set the index system. It is shown in table 1:

Table 1 Total performance index system

\begin{tabular}{l|l}
\hline \multicolumn{1}{c|}{ level 1 index } & level 2 index \\
\hline cost index & $\begin{array}{l}\text { Total costs control;A single consumption cost;Personnel cost } \\
\text { control;Investment control;Maintenance costs;Tool accessories } \\
\text { investment;Management cost;Other costs }\end{array}$ \\
\hline quality index & $\begin{array}{l}\text { Audit evaluation;Quality accidents;A test pass rate;After defects;Quality } \\
\text { process control;Industrial waste rate;Rework rate }\end{array}$ \\
\hline production and & $\begin{array}{l}\text { Yield;Production of equilibrium;Single consumption of working } \\
\text { hours;Working hours use;Time account control;Equipment failure } \\
\text { rate;Equipment management;Logistics accuracy;Claim coincidence rate }\end{array}$ \\
\hline Staff system & $\begin{array}{l}\text { Team building;Rationalization proposal;Process optimization;5s } \\
\text { management;Standardized operations }\end{array}$ \\
\hline
\end{tabular}

Using factor analysis method and Minitab tool carries on the correlation analysis for the level2 indexes to avoid duplicate information. The eight indexes of cost index is carried on data analysis by taking the cost index for example.

The three key indexes of cost index include: total cost control, investment control and single consumption costs. The index system established by the selected key indicators is shown in figure 2 .

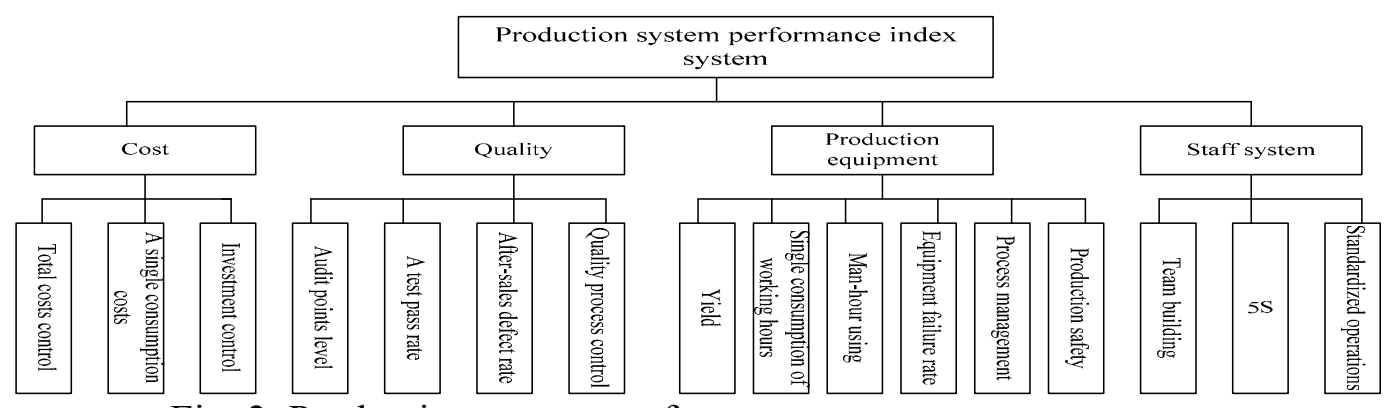

Fig. 2 Production system performance measurement system 
The Determination of Index Weight. Total index: $\mathrm{C}_{1}$ : cost; $\mathrm{C}_{2}$ : quality; $\mathrm{C}_{3}$ : production equipment; C4: employee system. In the case of $\mathrm{C}_{1}$.

Points index: $\mathrm{C}_{1}$, for example, $\mathrm{C}_{11}$ : total costs control; $\mathrm{C}_{12}$ : single cost cost; $\mathrm{C}_{13}$ : the investment control.

The judging matrix of indexes can be builded according to statistical data, specific as follows:

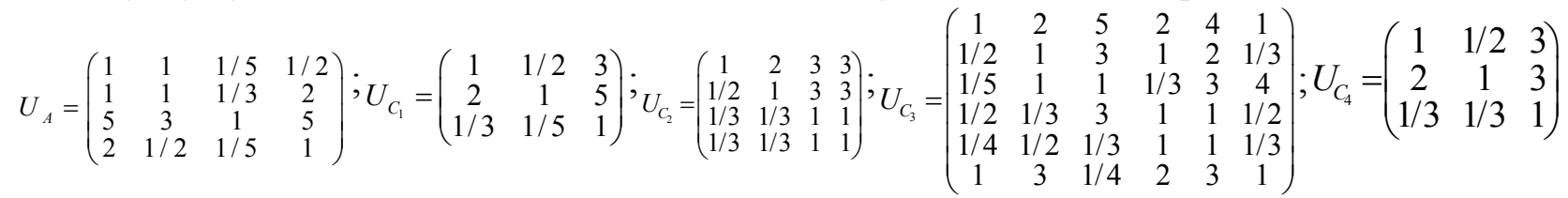

Take Judgment matrix A for example: the matrix is summed by row, then it is normalized, it is concluded that:

$$
W=\frac{V_{i}}{\sum V_{i}}=\left(\begin{array}{c}
\frac{0.562}{0.562+0.904+2.943+0.669} \\
\frac{0.904}{0.562+0.904+2.943+0.669} \\
\frac{2.943}{0.562+0.904+2.943+0.669} \\
\frac{0.669}{0.562+0.904+2.943+0.669}
\end{array}\right)=\left(\begin{array}{l}
0.111 \\
0.178 \\
0.580 \\
0.132
\end{array}\right)
$$

The importance of four levell indexes of level1 index same operation is drew in the same way:

$$
V_{1}=\left(\begin{array}{l}
1.145 \\
2.154 \\
0.405
\end{array}\right) W_{1}=\left(\begin{array}{l}
0.309 \\
0.582 \\
0.109
\end{array}\right) ; \quad V_{2}=\left(\begin{array}{l}
2.060 \\
1.456 \\
0.577 \\
0.577
\end{array}\right) W_{2}=\left(\begin{array}{l}
0.441 \\
0.312 \\
0.124 \\
0.124
\end{array}\right) ; \quad V_{3}=\left(\begin{array}{l}
2.076 \\
1.000 \\
0.802 \\
0.953 \\
0.490 \\
1.285
\end{array}\right) W_{3}=\left(\begin{array}{l}
0.314 \\
0.151 \\
0.121 \\
0.144 \\
0.074 \\
0.194
\end{array}\right) ; \quad V_{4}=\left(\begin{array}{l}
1.145 \\
1.817 \\
0.481
\end{array}\right) W_{4}=\left(\begin{array}{l}
0.333 \\
0.528 \\
0.140
\end{array}\right)
$$

The judgment matrix is carried on consistency check, C.R. ${ }_{\mathrm{A}}=0.064, \mathrm{C} . \mathrm{R} .1=0.004, \mathrm{C} . \mathrm{R} .2=0.023$, C.R. $3=0.028$, C.R., $4=0.023$, they are less than 0.1 , they pass the consistency check.

\begin{tabular}{|c|c|c|c|c|c|}
\hline \multirow{2}{*}{$\begin{array}{l}\text { The } \\
\text { sub-indexes } \\
\text { comprehensi } \\
\text { ve weight }\end{array}$} & $\mathrm{C}_{1}$ & $\mathrm{C}_{2}$ & $\mathrm{C}_{3}$ & $\mathrm{C}_{4}$ & \multirow{2}{*}{$\begin{array}{c}W_{i}^{\prime}=\sum_{j} w_{j} v_{j i} \\
(\mathrm{j}=1,2,3,4 ; \mathrm{i}=1,2,3,4,5,6)\end{array}$} \\
\hline & 0.111 & 0.178 & 0.580 & 0.132 & \\
\hline Level1 index & \multicolumn{4}{|c|}{ The weight of relative levell index } & The weight of relative total index \\
\hline $\mathrm{C}_{11}$ & 0.309 & & & & 0.034 \\
\hline $\mathrm{C}_{12}$ & 0.582 & & & & 0.064 \\
\hline $\mathrm{C}_{13}$ & 0.109 & & & & 0.012 \\
\hline $\mathrm{C}_{21}$ & & 0.441 & & & 0.078 \\
\hline $\mathrm{C}_{22}$ & & 0.312 & & & 0.055 \\
\hline $\mathrm{C}_{23}$ & & 0.124 & & & 0.022 \\
\hline $\mathrm{C}_{24}$ & & 0.124 & & & 0.022 \\
\hline $\mathrm{C}_{31}$ & & & 0.314 & & 0.182 \\
\hline $\mathrm{C}_{32}$ & & & 0.151 & & 0.088 \\
\hline $\mathrm{C}_{33}$ & & & 0.121 & & 0.070 \\
\hline $\mathrm{C}_{34}$ & & & 0.144 & & 0.084 \\
\hline $\mathrm{C}_{35}$ & & & 0.074 & & 0.043 \\
\hline $\mathrm{C}_{36}$ & & & 0.194 & & 0.113 \\
\hline $\mathrm{C}_{41}$ & & & & 0.333 & 0.044 \\
\hline $\mathrm{C}_{42}$ & & & & 0.528 & 0.070 \\
\hline $\mathrm{C}_{43}$ & & & & 0.140 & 0.018 \\
\hline
\end{tabular}

The sub-indexes comprehensive weight is calculated, it is shown in table 2:

Table 2 The sub-indexes comprehensive weight

The Fuzzy Comprehensive Evaluation. In this paper, the evaluation standard is divided into A, B, C, D four grades based on the clustering analysis method. A: $X=100$ points, the goal and task of the department is done above norm, all aspects of the work are very satisfactory; $\mathrm{B}$ : $\mathrm{X}=80$ points, the 
goals and tasks of department is done better completely; $\mathrm{C}: \mathrm{X}=60$ points, the objectives and tasks are basically completed; $\mathrm{D}: \mathrm{X}=40$ points, the goals and tasks of department is not done completely.

Take the locomotive department as an example to carry on fuzzy comprehensive evaluation. Such as total cost control target of locomotive department is evaluated, $30 \%$ of the people consider A, membership degree of the index is 0.3 . After finishing, the fuzzy matrix of the locomotive department is concluded that :

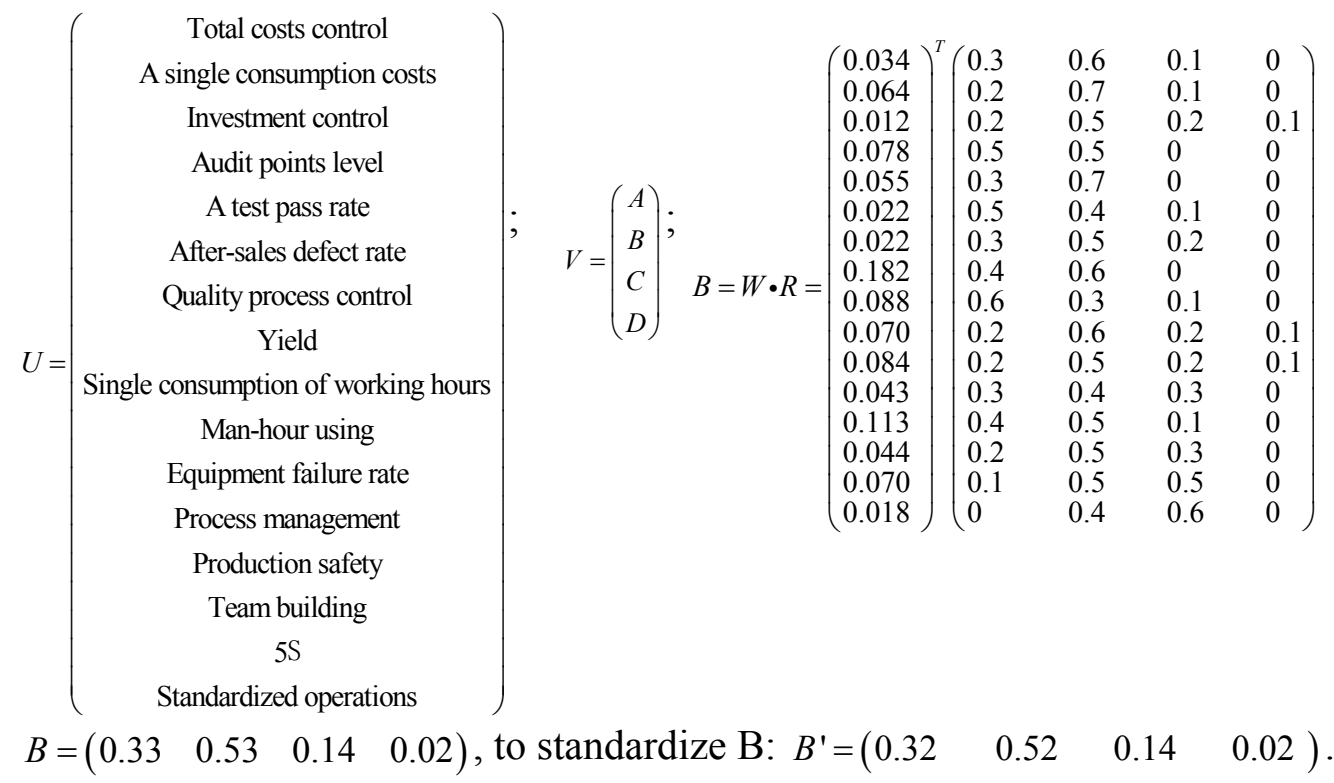

The evaluated scale: $\mathrm{V}=(100806040)$, the value is converted to a certain scalar: $D=C \cdot B^{\prime^{T}}=\left(\begin{array}{llllll}100 & 80 & 60 & 40\end{array}\right)\left(\begin{array}{llll}0.32 & 0.52 & 0.14 & 0.02\end{array}\right)^{T}=83.04$.

The result of fuzzy evaluation is saw that the goals and tasks of department can be completed by performance evaluation of locomotive department, it works well.

\section{Summary}

According to enterprise's disaggrega-tire and refined target, this paper constructs the X company performance management total system. It takes locomotive department as the research object, the performance appraisal is carried on. The performance evaluation is established a index system for locomotive department, and the weights of index system are calculated, fuzzy comprehensive evaluation is carried on finally, the ultima scalar value of locomotive department is 83.04 , it works well. The performance evaluation system of $\mathrm{X}$ company manufacturing system was established through study, so that the $\mathrm{X}$ company for the production department performance evaluation is effectively solve. It can be expand to manufacturing enterprises, the production performance management system is constructed for the manufacturing enterprise system, it can be provided some reference for the industry to carry out the department performance evaluation.

\section{References}

[1] Z. Zhou: Human Resource Management Tutorial (Shanghai University of Finance and Economics Publications, China 2001). (In Chines)

[2] Peter Senge: Fifth discipline (Shanghai Sumerian Publications, China 2001). (In Chines)

[3] H. Zhou, L.R. Long: The Progress in Psychological Science, Vol.13 (2005) No.6, pp.806-913. (In Chines)

[4] X.J. Chen, C.M. Wang: Psychological Science, Vol. 26 (2003) No.2, pp.212-214. (In Chines)

[5] Y.H. Fu, Y.L. Xu: Performance Appraisal and Performance Management (Electronic Industry Publications, China 2009). (In Chines) 